\title{
Women's participation in a radical trade union movement that claims to be feminist
}

9964 words

\section{Abstract}

This article investigates the under-researched topic of women's representation in radical unions, drawing on an in-depth case study of the French SUD movement. In addition to an overview of the institutional and organizational dynamics of unions' 'inequality regimes', it offers a contextually grounded analysis of the barriers and enablers of women's participation in SUD Unions. More specifically, this research reflects on the complex interrelationships between class and gender in class-based militant trade unions that claim to be feminist but fail to support working-class female workers' participation.

Keywords : gender, equality, radical trade unions

\section{Introduction}

The literature on "radical political unionism" (Upchurch et al. 2009) offers contrasting views on its capacity to propose a convincing alternative to the declining European trade union movement (Connolly et al. 2014). Whereas some research casts doubt on the growth in the foreseeable future (Mcllroy 2012) of "radical" trade unions that promote a more militant approach to organizing members through repeated threats and use of strike action alongside a politically engaged form of left-wing trade unionism (Connolly and Darlington 2012), others examine different aspects of the challenges facing unions in respect of collective bargaining or member representation (Connolly and Darlington 2012). Debates on organizing strategies highlight the need for radical unions to broaden their occupational base to include precarious young workers in the private sector (Connolly 2010; Denis and Thibault, 2014) and/or professional and managerial staff in 
the public sector (Denis 2012). Whereas some of these unions are well established in feminized public services and have equality structures (such as $\mathrm{RMT}^{1}$ in the UK), little attention has been given to women's participation issues. One of the reasons for this lack of interest can be found in the fact that many radical unions operate in maledominated industries, especially in the UK (fire service, railways), which is less the case in France. The SUD movement comprises over 40 unions in different industries, including mixed or female-dominated sectors such as post and telecommunications, local government, health and education. Furthermore, some of the militant unions' organizational characteristics, such as small size (Kirton, 2015a), decentralized structures (Cobble, 1990) and grass-roots democracy (McBride, 2001), should, in theory, facilitate women's participation.

Research on women's union representation has argued for contextually/historically grounded analysis (Kirton 2015a; Milkman 2016) as a means of understanding the structure and dynamics of unions' "inequality regimes", defined as the "interlocked practices and processes that result in continuing inequalities in all work organizations » (Acker 2006). Various factors should be taken into account, it is argued; they include size (Kirton 2015) and the period of foundation (Milkman 2016), a union's capacity to foster collectivism rooted in occupational community (Saundry and McKeown 2014; Sayce et al. 2006) and professional identity (Author and XXX), the presence and type of gender equality strategies, whether liberal or radical (Jewson and Mason 1986) and women's agency (Briskin 2006). Whereas feminist historical research has criticized the union movement's tendency to thrive on exclusionary solidarity (Milkman, 1990) and to subordinate gender to class concerns (Cockburn 1983), the role of class ideology in women's under-representation by/in contemporary unions has, with a few exceptions,

\footnotetext{
${ }^{1}$ National Union of Rail, Maritime and Transport Workers
} 
been neglected, (Dean 2015). This lack of attention is probably linked to the fact that European trade unions (no longer) claim to be socialist/Marxist and that femaledominated professional occupations in the public sector are now the main area of union growth. Any reference to "class struggle" seems to have vanished from most unions' agenda and research on young activists in non-radical unions has shown that they rarely assert class (or feminist) consciousness (Moore 2011). Research on radical unions also tends to be more cautious in terms of union members' politicization (Denis 2012). However, emergent class and gender identifications (Moore 2011), as well as their possible concomitance (Kirton and Healy 2013), have been identified and, in the case of union activism, can be fostered by union equality structures, such as women-only courses (Kirton and Healy 2004), and experience of gendered and class-divided workplace relations.

We argue that the complexity of class and gender relations is critical to any understanding of women's participation in radical trade unions, especially when these unions claim to be feminist and attract qualified and professional women, which is the case with the SUD movement and its national umbrella organization, Union Syndicale Solidaires (referred thereinafter as Solidaires). While describing themselves as radical and considering victimization as the price of their commitment (Denis 2016), most SUD activists have high levels of qualification, even when they work in low-paid jobs (Béroud et al. 2011). This characteristic contributes to the specificity of SUD unions in the French context, often described as run by "intellectuals", and interferes with the way gender and class identifications play out at the organizational and individual levels (see Table 1).

This article contributes to the prolific research on women's participation in trade unions by presenting a recent case study on the SUD movement. It provides some original 
insights into an atypical and under-researched section of the French union movement and offers some reflections on the relationships between class and gender in radical unions. It draws on fieldwork undertaken between 2014 and 2016, involving semistructured interviews with a range of female activists and officials, documentary analysis and survey results. The article begins with a review of the debates and key issues from the literature on the dynamics of inequality regimes in the trade union movement. Research methods, both qualitative and quantitative, are presented next, before the findings are discussed. This section starts by revealing the dynamics of gender equality policies since the founding of the SUD movement. Second, it explores the characteristics of SUD unions' specific inequality regime, which combines favourable conditions for women's participation and disadvantageous institutional and organizational barriers. The third part discusses the interconnection of class and gender. Finally, the conclusion offers reflections on the contribution the SUD case study makes to academic debate and underlines the influence and limitations of "insider feminist activists" (Banaszak 2010) in the promotion of equality.

\section{Women's union participation}

Previous research has shown that different external factors contribute to the underrepresentation of women in trade unions; they include the gender segregation of the labour market and the concentration of women in precarious and part-time work and the gendered division of domestic labour. As political scientists would put it, women have less biographical availability for activism in trade unions or in contentious political activity (McAdam 1986). Research has shown that those without obligations will be more likely to engage in activism. However, some biographical contexts, such as being married and having children, can provide social support for activism and keep people engaged over time (Corrigall-Brown 2012). Besides, research has shown that having knowledge 
and education is critical for explaining political (Wilkes 2004) and union activism, especially for women (Author and X). Alongside individual resources, previous research has emphasized the role of groups/organizations in creating incentives (or not) for activists to maintain their commitment, notably by contributing to the on-going creation of gender, class and racial inequalities.

In attempting to understand the changes that have taken place in gender relations in trade unions, scholars have also argued that significant attention should be paid to gender equality policies, often depicted as the main enabler for the development of an inclusive union culture (Kirton 2015b; Parker 2006). However, these policies interact in complicated ways with union practices and culture and the organization of union careers (Ledwith et al. 1990; Author and XXX). The durability of gendered representations of successful (heroic) leaders (Briskin, 2011b) and of informal selection processes tends to reproduce gender, racial and class inequalities. Depending on the characteristics of their internal union labour market (Author and XX) - type and number of full-time positions, retention levels, transparency of recruitment and promotion procedures - underrepresented groups might find it difficult to access leadership positions. On the other hand, in smaller organizations (Parker 2006; Sayce et al. 2006) there may be more opportunities to participate but time and location issues are detrimental to women with domestic responsibilities (Kirton 2015a). Democratic and participatory union leadership is also usually associated with strong and inclusive workplace unionism (Greene et al. 2000). A stance of this kind does not preclude the maintenance of strong power relations with management, including strike action, but hostile industrial relations, higher risk of victimization and excessive demands on union representatives can be damaging to women's participation (Kirton 2015a; Author et XX). 
Contrary to gendered misconceptions about organizing women, research has established that women have always been able to organize and build creative coalitions with other social movements in order to defend their interests (for detailed discussion, see Yates 2006). Militancy is therefore not detrimental per se to women's participation in union activity. However, women's experiences of strikes reveal persistent tensions between class and gender identifications both during and after strikes. While professional women (such as nurses, Yates 2010; Briskin 2011a) and "pink-collar" employees (Crain 1994) have found ways to represent workers' sense of their interests as both workers and women, they have rarely chosen to frame their mobilization as "women's strikes". Identification with feminism seems to be even more difficult for working-class women, as it can threaten family life and relationships with men (Shaw and Mundy 2005; Gallot and Meuret-Campfort 2014) and women's respectability (Skeggs 1997).

However, in France, as in the UK, it is still difficult for women in trade unions to identify with feminism, even in non-radical mixed unions (Author XX; Pochic 2014; Trat 2006). Many feminist women leaders have experienced sexism and been ostracized by their male colleagues, especially when they served as women's officers. While some women union leaders, mainly in feminized contexts, claim to practise "feminist leadership" (Kirton and Healy 2012), assimilation strategies and the adoption of masculine leadership approaches seem to be a much more effective route to union legitimacy (Author and XX). As we previously argued, professional women in moderate unions usually prefer to use the "qualification lever" rather than their feminine and/or feminist leadership style in order to assert themselves in their union position (Author and XX). This strategy implicitly exposes unspoken class relations amongst women trade unionists and calls for a nuanced analysis of class and gender interactions, not only from an institutional point of view (Dean 2015, 2017) but also at the level of individual forms of identification. 


\section{Research methods}

This research was carried out in collaboration with Solidaires over a two-year period (2014-2016). Contacts were made through academic colleagues who were (and still are) engaged in on-going research with/on the SUD movement (Béroud et al. 2011). Building on previous research on women and trade unions, the author and Solidaires discussed the rationale for and ways of investigating women's participation issues, in a context of union renewal, and examining women's views on unions' gender equality strategies. Solidaires was considering strengthening its equality strategy and was about to discuss a women's motion covering a wide range of women's issues in the labour market and the wider society at its 2014 annual general meeting. At the time, a proposal to introduce more compelling internal equality measures, such as quotas, was considered but postponed. The fear was expressed that these new measures could be difficult to implement because of the lack of women sufficiently well recognized and willing to take on senior leadership positions and resistance from influential affiliated (maledominated) unions.

It was decided to undertake research on barriers to and enablers of women's union participation, using a mix of qualitative and quantitative methods. First, the case study draws on in-depth semi-structured face-to-face interviews with 30 women in 16 SUD unions in different sectors (see Table 1), of various sizes and levels of feminization. Potential interviewees' profiles were discussed with Solidaires in order to identify women activists at different stages of their union career: activism, consolidation and directing (Ledwith et al. 1990). We chose to focus on formal and consistent levels of activism, knowing that the implicit assumption of continuity and linearity of this career pattern is a masculine construct (Kirton 2006). Our aim was to understand the characteristics and challenges of women's union careers in different union contexts, as 
well as their opinions on equality structures. All these interviews were analysed using biographical tables in order to examine the interactions between work, family and union lives, with a specific focus on the embeddedness of individual trajectories in unions' organizational and institutional dynamics, including the influence of gender equality policies.

Table 1

Second, a quantitative survey was designed (see Table 2) that took into consideration questions (and survey results) utilized in previous research on SUD unions (Béroud et al. 2011) and other more specific topics. The survey enabled us to collect a broader range of women's views on: (i) existing equality policies in their union; (ii) the development of mixed or women-only equality measures (iii) their desires and opportunities to take on further union responsibilities; (iv) barriers to union participation; (v) feminist identification and forms of political activism, including women's rights. The survey was approved by Solidaires and ran during Solidaires' two-day annual women's conference in March 2014. It attracted 145 responses, giving a response rate of $70 \%$. The respondents were mainly women (95\%). Fifty-three per cent of them had been union members before joining SUD. Most of them held leadership responsibilities at the local, regional or national levels. Three mixed or female-dominated unions, including one of the largest SUD unions, were represented: SUD PTT (post and telecommunications, 31\%), SUD Education (education, 18\%) and SUD Santé Sociaux (health, 14\%). SUD Rail, which is also one of the large but male-dominated SUD unions, was significantly underrepresented.

Table 2 


\section{An atypical union movement}

Solidaires, Unitaires et Démocratiques (SUD) unions emerged in the late 1980s, following the breakaway of groups from the Confédération française démocratique du travail (CFDT) in various public sectors (health, post and telecommunications and railways). Solidaires was founded later, in 1998, uniting other SUD unions formed in the meantime with small independent unions grouped together in a former organization known as "Le Groupe des Dix" (Denis 2001). Solidaires is not a union confederation per se. It is a representative body with little power over its affiliated unions and few national full-time officials. In the French union context, it is a small "confederation", with approximately 100,000 members ( $70 \%$ in the public sector and privatised public companies), that is not recognized as representative at the national level under the 2008 rules. However, SUD unions have gained the right to represent workers in 42 industrial sectors. Since most SUD unions had to fight to obtain recognition under the former legal regime, in which only five confederations were recognized as representative, these mixed results indicate a form of institutional recognition.

Nevertheless, the SUD movement remains atypical in the contemporary French union landscape. Whereas its radicalism certainly has its antecedents in the history of the French trade union movement, its class-based and left wing political orientation, as well as its militancy, set it apart from existing union confederations. According to previous research, activists share a set of specific values (Béroud et al. 2011), including a desire to build a "fighting union", to achieve social transformation and to oppose neoliberal reforms. Furthermore, most SUD unions also support a unique conception of internal democracy based on: consensual decision-making, avoidance of full-time officers, rotation of elected officials and strong workplace unionism. Last but not least, Solidaires' 
wider goal of achieving social transformation encompasses the "emancipation of men and women so that they are able to act on their working environment and be actors in their lives" (Solidaires 2014). Solidaires, which was led from 2001 until 2014 by Annick Coupé, a female co-founder of SUD-PTT, is explicitly committed to a feminist agenda that aims to advance equality in the workplace and in the society. This pledge was first mentioned in 2001 and was reaffirmed at the 2014 annual general meeting, where a specific women's motion was debated. This motion called for better representation of women within SUD unions and in the workplace (recruitment, jobs, wages, work-life balance) and also covered broader issues such as educational inequalities, health, housing, prostitution and violence against women. It also incorporated the issue of immigrant and undocumented women, which is very rare in the French union context. Overall, the motion was very close in its position to materialist feminism, which originated partly from the work of French feminists and highlights capitalism and patriarchy as central to understanding women's oppression (Delphy 1980).

\section{The role of insider feminist activists}

The first SUD unions founded in the late 1980s - such as SUD-PTT and SUD-CRC-Santé Sociaux - included experienced and politicized women activists who had sometimes experienced sex discrimination in the Trotskyist or Maoist groups ${ }^{2}$ in which they had participated in the 1970s (Coupé 2003) and held leadership positions in their CFDT federation where they had taken part in the internal political debates on gender equality (Wolf 2011). They had also participated in CFDT equality structures and defined themselves as feminists at the time when the CFDT was developing a society-wide approach to feminism (Le Brouster 2009). They promoted equality policies in the newly created SUD unions, even if "other priorities prevailed at the time of the creation of the

\footnotetext{
${ }^{2}$ Such as Parti communiste marxiste-léniniste de France and Ligue Communiste Révolutionnaire.
} 
first unions and at a time when little progress was being made on the feminist front" (Coupé 2003). Later on, some of them got involved in the 1990s feminist movement, mainly within CADAC (Coordination des associations pour le droit à l'avortement et à la contraception) which brought together various feminist associations, the MFPF (Mouvement Français pour le Planning Familial), women's sections or commissions in the main trade unions and political parties, and CNDF (Collectif national des droits des femmes) formed in January 1996 as an offshoot of CADAC. As Annick Coupé points out, for her, the issues of contraception and abortion have always been at the heart of women's emancipation (Coupé 2003). Most of them also helped to promote other women, "lifting as they rose" (Kirton and Healy 2012), and pushed for the feminization of their union, as Jacqueline's biography exemplifies.

Jacqueline is a social worker by training. However, in 1981, following the doctrine of her leftwing group, Ligue Communiste Révolutionnaire, she trained to be a lathe operator and found a job in a large factory. She joined the CGT and became a union rep. She was proud to be accepted by her male co-workers. "I was their mascot. It was the first time they had seen a girl in their workshop. Their views changed somewhat when I became a CGT leader." In 1988, she was fired after her participation in a 3-week strike. She then decided to apply to the national telecom company, France Telecom. She started as a telephonist, in a very female-dominated environment, and joined the CGT. But she did not like the way the CGT was led in this company and her Communist union colleagues did not appreciate her Trotskyist affiliation. She decided to join SUD-PTT, which had just been set up, but she finally decided to change jobs. She became an employment counsellor and joined the newly created SUD-ANPE. "We had to build everything, it was great. We were only two women; we had to make our voices heard. We also had to organize the union meetings at night because we had no rights". After a while she took on more responsibilities and was elected as a Solidaires national official. She is 61 . She has never had children. It was a choice she made with her partner, who is a long-term activist. She is a 
committed feminist and has never been afraid of working in male-dominated environments, including unions. "It easier to be a feminist in Solidaires than in the CGT. However, feminism is not shared $100 \%$, including by women. Some of the younger generation think that there are other more important causes to fight for" (woman, employment counsellor, 61, no children, Solidaires).

Their politicization did not always reflect the attitudes of their male union colleagues or of women at the workplace level (Wolf 2011), depending on sector. This finding seems to be corroborated by recent surveys. When asked what the main challenges for the union movement were, the 2008 annual general meeting delegates ranked gender equality in $9^{\text {th }}$ position (out of 11 propositions), way behind the defence of employment rights, resistance to neoliberalism and defence of public services (Béroud et al. 2011), revealing the centrality of class in the framing of union struggle.

\section{Unequal feminization and limited equality policies}

In terms of representativeness, $75 \%$ of the survey respondents indicated that the gender composition of their local union was balanced, bearing in mind that the majority came from mixed or feminized unions. When it comes to leadership, this rate gradually diminishes. Fifty-eight per cent thought that a gender balance had been achieved at the branch level, $34 \%$ at the regional level and 38\% at the federal level. According to Béroud et al. (2011), $28.5 \%$ of delegates at the Solidaires annual general meeting in 2008 were women. A more recent unpublished survey conducted during the 2014 annual general meeting indicated that women represented $37 \%$ of the delegates. This increase hides great disparities between unions, depending on workforce feminization levels, and the permanence underrepresentation of women in union leadership positions. The share of women on Solidaires national executive committees or attending national meetings is 
put at $30 \%$. In 2014, it was decided to replace Annick Coupé on her retirement by one man and one woman working together as national representatives of Solidaires. A small number of women lead large SUD unions, including the male-dominated SUD-Rail (railways), or are elected officials. However, gender equality does not seem to be identified by survey respondents as the main area for the improvement of internal democracy (Béroud et al., 2011). In 2008, women's participation was seen as the least important issue ( $7 \%$ of responses) for the future of SUD unions, behind the need to train young activists (48\%), obtain recognition in the private sector (38\%) and attract more members (36\%).

Being small organizations, Solidaires and SUD unions have limited equality policies. Solidaires has a national women's commission and a more recent "gender and sexuality" commission, three equality courses run by a small number of committed activists on equality in the workplace, violence against women and gendered stereotypes and one annual women's conference held jointly with CGT and FSU since 1997. SUD-PTT is the only union with two reserved seats (out of 9) on its national executive committee (secrétariat fédéral), one for women and one for activists from outside Paris. In the other unions, our survey indicates that four types of "measures" are used to address equality issues. Thirty-eight per cent of the respondents indicated that their union had a mixed women's commission. Twenty per cent mentioned the organization of specific debates and training events (19\%). Ten per cent cited a specific "women" rubric in the union press. Thirty per cent of the respondents mentioned the non-existence of specific equality measures.

The underrepresentation of women in union leadership roles is comparable to other French trade unions, but it is quite surprising for a union that (also) claims to be feminist. 
The predominance given to class struggle within SUD unions partly explains the subordination of the struggle for gender equality, but other institutional factors linked to union recognition and revitalization issues explain the lack of importance given to feminization by activists. Gender equality has been pushed by a minority of female leaders who have made their mark in some larger, more feminised unions, perhaps giving the impression that equality has been achieved. Their individual achievements hide the fact that the feminization process remains not only uneven, but (very) selective.

\section{The specific conditions of women's engagement}

SUD activists have the distinctive characteristic of being underrepresented in blue-collar jobs and overrepresented in professional positions (Béroud et al. 2011), even if younger activists are more likely to be in low-paid jobs (mostly because of the difficulty of finding a job matching their qualifications). Activists are also usually highly qualified. Our survey confirmed these trends (see Table 2). Only 15\% of respondents were working in the private sector and more than $70 \%$ were civil servants and/or working in large public companies. Fifty-six per cent had a university degree (and $24 \%$ a master's degree). Only 9\% were blue-collar workers and $38 \%$ were white-collar workers or professionals. Furthermore, $75 \%$ were working full-time and most of them had teenage or grown-up children, circumstances that usually favour women's participation. These characteristics can be explained by the greater recognition SUD unions enjoy in the public services, including two large public companies - in the telecom and rail industries - that provide job security, generous union rights and facility time.

Moreover, many SUD unions operate in female-dominated or mixed occupations, where there is a strong sense of gendered solidarity and robust occupational identities (nurses, teachers, museum attendants). Women's participation is encouraged by the small size of 
local unions and, in many cases, their recent foundation. Rules on union democracy (mandate rotation, no full-time officers) and the lack of applicants (union density in France is under $8 \%$ on average, $15 \%$ in public services) also help to open up opportunities for women who would like to get involved, as Isabelle's biography exemplifies:

In 2000, after finishing her BTEC in IT, a large IT maintenance company hired Isabelle. Very quickly, she was recruited by the CFDT and elected as union representative, sitting on various committees. "I have always had a big mouth. I have always defended my colleagues even when I was not a union rep". She was the only woman is her department, but there were other women in the company. At the time, she "did not feel there were gender equality issues". She then decided to move on to become a plumber, a job that she had always dreamed of but that her parents forbade her to train for. She attended a one-year course with 28 other students, all of them male. Once again she was the only woman. She had some difficulties with some of the students and a sexist teacher who did not appreciate her work, but she passed her exam with distinction. A boiler maintenance company then hired her as a technician. She was the only woman in her team. She was surprised not to see any information about trade unions, given the size of her company (more than 1000 employees). After she started having troubles with her line manager, she decided to join a union. She went to see the CGT but never received the membership form. She then turned to the CFDT but the union leader told her that he needed to see her work first. She finally called SUD and was put on the list for the next elections. SUD managed to obtain $9.5 \%$ of the vote, which was not enough to be recognized as a negotiating partner but did allow one activist to sit on the works council. "I asked a lot of questions, I challenged the management and the other union reps". The CGT is the majority union but their reps are too close to management for her taste. She is the only SUD member in the company but she is well supported by her union, SUD-Industries. However, because she has disputes with management, she is being hassled by her line manager. She has been threatened with dismissal but has been supported by the labour 
inspector (Inspection du travail), unlike her CGT "comrades". She knows that she will never have any career progression in this company but she is committed to developing SUD. She has some time to dedicate to her union activity as her only child is grown-up and she lives on her own. She really enjoys working with her union colleagues: "SUD is very open, you can bring what you want and what you are, and they really stand up to the employer". Interestingly, during the interview, Isabelle has hardly ever associated her professional and union difficulties with being a black woman.

Most interviewees, especially those new to the union movement, also mentioned the importance of convivial relations between members and activists in the local union, echoing "relational union organizing" approaches (Saundry and McKeown 2013). Their experience of open debates, where everybody can participate equally irrespective of their union positions, and of operating within a consensual mode of decision-making was often mentioned as critical to the strengthening of women's commitment to the union.

\footnotetext{
'Why did the union become feminized? It's because of the way we operate. We use a consensual mode of decision-making. We can have strong disagreements, but we do not try to achieve a majority vote, we aim for a consensus. If the arguments are well explained, we listen. We do not try to impose our views on members. This is very different from other more traditional unions" (women, museum attendant, 46, no children, SUD Culture).
}

Compared to other French trade unions, SUD unions offer more opportunities for women' involvement. Their small size (Kirton 2015a), the focus on workplace unionism and internal democracy (Greene et al. 2000) and the rejection of full-time activists provide space for women's participation. The over-representation of SUD unions in the public sector and privatized public companies also facilitates women's involvement by providing full-time permanent jobs and union rights. However, as shown in previous 
research, union feminization remains selective depending on individual resources (Author and XX), the gender composition of the workplace and the social ties fostered within activist groups. Knowledge, education and fewer outside caring responsibilities are critical conditions for women's involvement (Le Quentrec and Rieu 2003; Haller 2017), but union practices are also crucial in maintaining their commitment.

\section{Distinctive barriers to participation}

Nevertheless, SUD unions display some organizational characteristics that can discourage women's participation. In the French pluralistic industrial relations system, unions' rights and facility time are determined by workplace election results. Because of their frequently marginal situation, SUD unions have fewer resources than other, bigger unions and are at greater risk of losing their right to represent workers (and the elected union positions associated with it). This puts considerable pressure on experienced activists and does not encourage new members to participate, since they are aware that their union rights can be easily lost and they could be exposed to managerial victimization without any "protection", as Catherine explains:

'We have a very demanding and stressful job which leaves little space for union activism. I understand that many members do not want to take on union responsibilities. We have very little facility time because we are a minority union and working for the union is even more exhausting. We need to train more activists but that also requires more work... So we end up relying on the same individuals. It is a vicious circle" (women, employment counsellor, 62, one grown-up child, SUD-Pôle Emploi).

Interestingly, our survey showed that $70 \%$ of the respondents did not want to take on more union responsibilities, knowing that their existing level of commitment was either quite strong or rather limited. Thirty-four per cent reported spending more than 10 
hours per week on their union activity and the same percentage said they devoted less than 2 hours to it (mostly younger women). Four main barriers to women's participation were mentioned. Work/life balance came first ( $32 \%$ of respondents), followed by "the burden of activism" (26\%), internal power struggles (18\%) and gender stereotypes (15\%). It might be surprising to see work/life balance issues so frequently mentioned by a population of middle-age activists with few domestic responsibilities $(60 \%$ of the respondents were more than 50 years old). One interpretation, linked to the second issue mentioned by the respondents, is that belonging to SUD brings about specific difficulties in terms of work/union life balance. Because their line managers rarely have much time for SUD activists because of their militant and conflictive union activism, they suffer frequent victimization (Denis 2016). Our survey shows that $45 \%$ of the respondents felt discriminated against at work, mainly because of their union role (63\%), sex (21\%) or both (21\%). However, as Maïwenn' biography illustrates, this victimization can be accepted and construed by SUD trade unionist as part of their union identity (Denis 2016).

In 1995, Maïwenn started working after leaving university, where she had started to study medicine but found it "was too competitive and individualistic". She moved in with her partner and had her first child when she turned 20. She took on lots of precarious jobs and finally applied for a permanent job at La Poste in 1998. She was hired and joined SUD-PTT after her probation period. As a junior worker, she had to cope with lots of overtime for which her line manager refused to pay her. She came from a union background but had bad memories of the CGT, which did not support her mother when she had had difficulties in her job. So when Maïwenn started having troubles with her manager, she joined SUD-PTT and got involved in a long strike over the implementation of the 35 -hour week. "We won. This is how I became an activist. I started getting involved in the union exec, but I did not have much self-confidence." When she was transferred to another office, she got more involved and spent half of her time 
doing union work. After splitting with her partner, she moved back to Paris with her two children and became a full-time union official in 2007. "They really wanted to feminize the union because we had as many women members as men". In 2009, she was asked to take on more responsibilities at the federation level. There were only 3 women out of 9 officials on the federal exec. "They are all men, they have big mouths, and it is difficult to find your voice". When the female general secretary left, she was asked to succeed her, but she refused. She had split up with her new partner because her union female friends helped her to realize and refuse to accept the situation of domestic violence that she was experiencing. She was then raising three kids alone. She did not want to be elected as a token woman. She is now considering going back to work but it is going to be difficult. She has not progressed in her career since she joined La Poste. SUD-PTT refuses to accept the "automatic wage progression" given to trade unionists. "Our position is: no victimization, no privilege". She does not see herself becoming part of the management against whom she has been fighting for so many years (and has suffered the consequences of so doing). She is considering becoming a social worker.

Gender relations can also be difficult in male-dominated unions, echoing the gender job segregation and sexist behaviours found in the workplace/industry. Female interviewees at SUD Rail (railways) and SUD Douanes (customs) recalled situations where they suffered from sex discrimination and harassment at work and in their union, as Elisabeth mentioned below. In more mixed environments, the difficulty in feminizing union activism and recruiting activists can stem from the need to challenge the hegemony of the male founders, which can require the intervention of experienced and feminist female activists, as Jacqueline mentioned above. The persistence of a heroic (Briskin 2011a) and masculine style of leadership, intrinsic to the social construction of militant activism, also constrains women's participation. In a more subtle way, the highly politicized and ideological nature of union debates, relying on grandiloquent and sophisticated speeches, can also discourage poorly qualified and less politicized 
members (Mélis 2010; Haller, 2017). Research in political science has shown that deliberative and participative democratic practices can contribute to the reproduction of class inequalities (Lenzi, 2009), as Anne puts it:

"We always have the same debates. In our exec, we have a majority of professionals. We are struggling to recruit administrative employees, $90 \%$ of whom are women. They are afraid of speaking in front of more highly qualified male union officials. We do not know how to solve the issue. We have only two female admins in our exec out of 35 members" (woman, factory inspector, 36, no children, SUD-Travail).

Compared with more institutionalized trade unions, SUD unions enjoy fewer rights and offer insecure union careers. Trade unionists are also more vulnerable to victimization, resulting in wage stagnation and frequent harassment (Denis 2016). Furthermore, as shown in previous research (Author XXX), equality policies do not always filter down through organizations, which may allow discriminatory practices to persist, whether they be obvious forms of sexism or more subtle forms of exclusion aimed at less experienced (and sometimes less qualified) female activists. However, in comparison with older female leaders, younger women seem to have more difficulties identifying and fighting against discrimination.

\section{A gradual feminist consciousness}

To judge from other studies on French trade unions (Author and XX), SUD women activists identify more strongly as feminists. Our survey shows that $76 \%$ of the respondents defined themselves as feminist and $93 \%$ declared themselves in favour of specific women's demands or campaigns. These results are biased by the nature of the conference attended - a women's conference - and by the overrepresentation of 
women committed to the feminist cause. Seventy-three per cent had attended this conference in the past and $85 \%$ were sometimes or often engaged in women's issues/struggles in their local union.

Except for the interviewees involved in union (gender) education and women's or LGBT commissions, interviews with younger activists (age 40-45), including Maïwenn and Isabelle mentioned above, provided nuanced views on feminism. Most of them were raised in mixed and egalitarian family and school environments. They rarely identify with the feminists from the 70s, often stereotyped as women "burning their bras". Their feminist identification developed gradually through their experience of sex discrimination in the workplace (demotion after maternity leave or unequal pay, for instance) and their union, attendance at union training events, such as the annual women's conference and discussions with feminist union leaders, and sometimes their experience of domestic abuse or gender inequality at home. They also mentioned the promotion of gender equality/diversity policies by the French government and the development of mandatory collective bargaining on gender equality in large companies as levers for their own and their union's commitment to establishing gender equality (including in their own homes), as explained by Muriel:

\footnotetext{
"Some years ago, I would not have defined myself as feminist. My image of feminism was very much influenced by the ' 68 generation, which I had difficulty identifying with. I think many French people share this caricatured representation, unfortunately, because now I have realized all the battles these women had to fight to get the rights that we are trying to protect now. For me, being feminist is to understand that when we struggle for women's rights we struggle for equality. And this notion is critical because it fits with our union values. I do not use some of the notions adopted by the feminist movement, such as patriarchy, but I understand them" (woman, accounts employee, 42, 2 children, SUD Finances).
} 
However, many interviewees mentioned their solitude and their difficulties in sharing gender equality concerns not only within their unions but also in their families. As found in previous research, feminist identification can be seen as a threat to traditional family models and give rise to tense relationships with men at work and home, as Elisabeth recalls:

After a few years of precarious work in the hospitality and commerce industry, Elisabeth applied to SNCF to become a train driver "because they required a scientific baccalaureate and I had one". She was pregnant when she was hired, which earned her the disapproval of her manager and colleagues and therefore she had to wait two years to be trained. In 2001, when she finally entered the driving school, she decided to join the CGT because "there was one CGT member who had always been nice to me and told me that the most important thing is family life". She remained affiliated to CGT for 7-8 years and became a health and safety rep. After being sexually assaulted during a picket line by a colleague and none of the CGT activists present tried to defend her, she decided to join SUD-Rail. "It went well for a year, until they thought I was taking up too much space". Suddenly, her union began organizing meetings on Wednesdays when she was not working to care for her three children. The union leader, whom she describes as a "misogynist", told her that it was necessary to "know how to make sacrifices when being an activist". He never supported her in her fight to improve the situation of women, arguing "we are not going to take time for a fight where you are 150 girls in France driving trains out of 16,000 drivers! We don't have much union time, we need to have a real fight that affects everyone". She found a moment of respite in her participation in the union regional committee where she followed training on gender stereotypes and realized that "I was a man. Often when I talk about myself I say that I am a train driver. I denied all my femininity". However, after a year, Elisabeth decided to leave everything behind, knowing that no one would stand up against a powerful local union leader. She had 15 years' service and 3 children, which entitled her to an early retirement. She and her husband had plans to move to Senegal. They have gone through 
very difficult times in the last few years. He wasn't always very supportive to her, especially when she wanted to make a complaint after the sexual assault, and he was fed up with her working nights and weekends, on top of her union role.

Nevertheless, many interviewees and survey respondents, regardless of their generation, expressed their distrust of women-only measures. Only $45 \%$ declared themselves in favour of non-mixed structures. When she was a CFDT leader, Annick Coupé herself was against the implementation of solutions that she perceived as "technical", such as quotas, in favour of a political approach (Coupé 2003). Since then, she has changed her position, but she still considers that quotas should not be "an end in itself" and should not be isolated from the union agenda (Coupé 2003).

The reluctance to implement women-only measures can be explained by the negative reactions that these measures might generate within some unions and the lack of resources to implement them. It also conveys the influence of the French "republicanuniversalist" framing of equality that explains the long history of resistance to feminism (Delphy 2010) and the belated recognition of social and racial discrimination (Fassin 2002), as well as the reluctance to implement affirmative actions. Radical measures, such as quotas, have been resisted by many French feminists because they conveyed the idea that women could be classified as a specific category like any other social or racial group. It is only by arguing that women should not be considered a minority (Gaspard et al. 1992) and that sex difference is universal that some parts of the women's movement built up the necessary consensus to achieve the vote of a "parity law" in politics in 2000, thus preserving universalist principles (Bereni 2015). Overall, the idea of women-only structures can still not be taken for granted within the French feminist tradition, whether essentialist or materialist. 


\section{Conclusion}

Women are underrepresented in SUD unions and they seem unable to exceed the $30 \%$

"critical mass" of women leaders theoretically needed to support gender transformation (Kanter 1977), except in highly feminized trade unions. This difficulty can be seen as a paradox for a union movement that claims to be feminist, was led by a (feminist) woman for nearly 15 years and where women senior leaders have consistently acted as "critical actors" (Childs and Krook 2009) in setting up and coordinating women's commissions and training programmes at the national level and in some trade unions. These "insider feminist activists" (Banaszak 2010) have consistently fought to put gender equality on the union agenda and many of them were involved in the women's movement (Wolf 2011). Remarkably, as individuals, they did not seem to struggle to articulate gender and class concerns, probably because of their participation in other left-wing organizations where they had had the opportunity to develop and assert their feminist arguments. Many of them had only a small number of children (Wolf 2011), which confirms the importance of biographical availability for union participation. Unions are known to be "greedy institutions" (Franzway 2000), especially when they are small (Kirton 2015a). Having no partner or a supportive one also seems to have been a key condition for the persistence of their engagement. When possible, they took advantage of newly created union structures and democratic union rules to encourage women's participation. Moreover, in the 2000s, the institutionalization of gender equalities in the workplace, under new legislation, offered new levers for raising consciousness of rights amongst female workers and fellow trade unionists and helped to sustain the unions' equality agenda. 
However, this case study also points to the limitations of "liberal" gender equality policies in a small and minority union movement. Because of the decentralized and democratic nature of the SUD movement, national/federal structures are not allowed to interfere and cannot discipline local unions for their discriminatory practices.

Furthermore, as they are often in a minority position and have few resources, SUD unions face many organizational issues, including high risks of victimization. Achieving gender representation is not seen as a critical challenge, compared with the need to recruit and retain members, train activists and secure union recognition. Many studies have shown that equality is easier to achieve in large and growing organizations (Huffman et al. 2010), which is rarely the case with SUD unions. Likewise, this case study confirms the idea that symbolic actions promoting equality "from above" through the election of a few women officials have limited effects. The imposition of more radical measures, such as quotas and reserved seats are necessary to challenge the organizational processes that contribute to the reproduction of gender (and race) inequalities. Although some Solidaires leaders, including men, are now convinced that the movement should aim for more drastic equality measures, they also fear that these new constraints on the election of union reps at the workplace level, which have been mandatory since the 2015 Rebsamen Act $^{3}$, will weaken unions' executive teams. The lack of trained female activists willing to take over federal or national responsibilities may constitute a big challenge if stricter equality rules are adopted.

Finally, the radical political stance of SUD unions poses specific questions in terms of the interconnections between gender and class. As found in previous research, the

\footnotetext{
${ }^{3}$ The Act imposes a balanced and alternating presentation. In practical terms, this means that the employer must inform unions of the proportion of men and women for each electoral college. Union lists will include a number of men and women corresponding to the proportion of men and women registered in the relevant electoral college and the lists will alternately consist of one candidate of each sex until there is no more candidates of either sex.
} 
prevalence of class-based union framing contributes to the subordination of gender concerns and the invisibility of gender inequalities (Acker 2009; Dean 2015), especially in male-dominated unions, but also in feminized ones. High levels of feminization at the workplace level and difficulties in comparing employment conditions with other maledominated occupations can create the impression that gender equality has been achieved. As we pointed out, younger female activists' identification as feminists developed gradually through a process triggered by their experience of sex discrimination and gender inequalities, which are more evident in male-dominated or mixed environments. Whereas feminist consciousness is essential if the neutral definition of class is to be challenged (Dean 2015), the social characteristics of SUD female leaders create unexpected class (race) and gender dilemmas. These (white) professional women tend to be exceptional in terms both of the biographical availability they have managed to create (sometimes causing friction with their partners) and their individual professional resources. Although they have sometimes been involved in specific actions or campaigns to foster gender equality in the workplace and their union, they have had difficulty to identify and address the systemic barriers encountered by women, including the massive impact of potential union victimization on low-wage workers' careers and the difficulties self-identification as a feminist can cause for working-class (and sometimes migrant) women. While they have (sometimes) managed to challenge gender relations in their union, they seemed to struggle to bridge the social distance that separates SUD activists from the members they seek to represent. This difficulty can be seen as a conundrum for a class-based union movement, but is shared by many trade unions in France and the UK (Author).

\section{References}


Acker, J. (2009). 'From glass ceiling to inequality regimes'. Sociologie du Travail, 51(2):

199-217.

Acker, J. (2006). Inequality Regimes. Gender, Class, and Race in Organizations'. Gender and Society, 20(4): 441-464.

Banaszak, L.A. (2010). The Women's Movement: Inside and Outside the State. New York \& Cambridge University Press.

Bereni, L. (2015). La bataille de la parité. Mobilisations pour la féminisation du pouvoir. Paris: Economica.

Béroud, S., Denis, J-M., Desage, G. and Thibault, M. (2011). L'Union Syndicale Solidaires : une organisation au miroir de ses militants. Research report. Lyon: Laboratoire Triangle.

Briskin, L. (2011a). 'The militancy of nurses and union renewal'. Transfer: European Review of Labour and Research, 17(4): 485-499.

Briskin, L. (2011b). ‘Union Renewal, Postheroic Leadership, and Women’s Organizing: Crossing Discourses, reframing Debates'. Labor Studies Journal, 36(4): 508-537.

Briskin, L. (2006). 'Victimisation and Agency: The Social Construction of Union Women's Leadership'. Industrial Relations Journal, 37(4): 359-379.

Childs, S. and Krook, M.L. (2009). 'Analyzing Women's Substantive Representation: From Critical Mass to Critical Actors'. Government and Opposition, 44(2): 125-145.

Cobble, D.S. (1990). 'Rethinking troubled relations between women and unions: craft unionism and female activism'. Feminist Studies, 16(3): 519-549.

Cockburn, C. (1983). Brothers. Male Dominance and Technological Change. London: Pluto Press.

Connolly, H. (2010). 'Organizing and mobilizing precarious workers in France: The case of cleaners in the SUD movement'. In: Thornley, C., Jefferys, S. and Appay, B. (eds) 
Globalisation and Precarious Forms of Production and Employment: Challenges for Workers and Unions. London: Edward Elgar.

Connolly, H. and Darlington, R. (2012). 'Radical political unionism in France and Britain : A comparative study of SUD-Rail and the RMT'. European Journal of Industrial Relations, 18(3): 235-250.

Connolly, H., Kretsos, L. and Phelan, C. (eds) (2014). Radical Unions in Europe and the Future of Collective Interest Representation. Bern: Peter Lang.

Corrigall-Brown, C. (2012). 'From the Balconies to the Barricades, and

Back? Trajectories of Participation in Contentious Politics'. Journal of Civil Society, 8(1): 17-38.

Coupé, A. (2003). 'Féminisme et syndicats'. Agone, 28: 134-145.

Crain, M. (1994). 'Gender and Union Organizing'. Industrial and Labor Relations Review, 47(2): 227-248.

Dean, D. (2015). 'Deviant typicality: gender equality issues in a trade union that should be different'. Industrial Relations Journal, 46 (1): 37-53.

Dean, D. (2007). 'Performing industrial relations: the centrality of gender in regulation of work in theatre and television'. Industrial Relations Journal, 38(3): 252-268.

Delphy, C. (2010). Un universalisme si particulier. Féminisme et exception française (1980-2010). Paris: Syllepse.

Delphy, C. (1980). "A Materialist feminism is possible". Feminist Review, 4 (1): 79-105. Denis, J.M. (2016). 'Les militant-e.s de SUD-PTT: entre discrimination co-construite et répression syndicale'. Terrains \& travaux, 29: 43-63.

Denis, J.M. (2012). 'The case of SUD-Rail : The limits of « radical political unionism »'. European Journal of Industrial Relations, 18(3): 267-272.

Denis, J.M. (2001). Le groupe des Dix: un modèle syndical alternatif?. Paris: La Documentation française. 
Denis, J.M. and Thibault M. (2014). ‘Des organisations syndicales en quête de renouvellement. Trajectoires militantes et expériences syndicales de jeunes militants de l'union syndicale Solidaires'. Nouvelle revue de psychosociologie, 2(18): 117-131.

Fassin, D. (2002). 'L'invention française de la discrimination'. Revue française de science politique, 52(4): 403-423.

Franzway, S. (2000). 'Women Working in a Greedy Institution: Commitment and Emotional Labour in the Union Movement'. Gender, Work and Organization, 7(4): 258-268.

Gallot, F. and Meuret-Campfort, E. (2015). 'Des ouvrières en luttes dans l'après 1968. Rapports au féminisme et subversion de genre'. Politix, 109: 21-43.

Gaspard, F., Le Gall, A. and Servan-Schreiber, C. (1992). Au pouvoir citoyennes ! Liberté, égalité, parité. Paris: Le Seuil.

Haller, Z. (2017). 'Genre et investissement syndical chez les enseignants. L'interdépendance des engagements'. La nouvelle revue du travail, 10, online. Healy, G. and Kirton, G. (2013). 'The Early Mobilization of Women Union Leaders - A Comparative Perspective'. British Journal of Industrial Relations, 51(4): 709-732. Huffman, M., Cohen, P. and Pearlman, J. (2010). 'Engendering Change Organizational Dynamics and Workplace Gender Desegregation, 1975-2005', Administrative Science Quartely, 55(2): 255-278.

Jewson, N. and Mason, D. (1986). 'The Theory and Practice of Equal Opportunities Policies : Liberal and Radical Approaches'. Sociological Review, 34(2): 307-34. Kanter, R. M. (1977). 'Some Effects of Proportions on Group Life'. American Journal of Sociology, 82(5): 965-90.

Kirton, G. (2015a). 'Anatomy of women's participation in small professional unions'. Economic and Industrial Democracy: 1-22. 
Kirton, G. (2015b). 'Progress Towards Gender Democracy in UK Unions 1987-2012'. British Journal of Industrial Relations, 53(3): 484-507.

Kirton, G. (2006). 'Alternative or parallel careers for women: the case of trade union participation'. Work, employment and society, 20(1): 47-66.

Kirton, G. (2005). 'The influences on women joining and participating in trade unions'. Industrial Relations Journal, 36(5): 386-401.

Kirton, G. and Healy, G. (2013). 'Commitment and collective identity of long-term union participation: the case of women union leaders in the UK and the USA'. Work, Employment and Society, 27(2): 195-212.

Kirton, G. and Healy G. (2012). 'Lift as you rise': Union women's leadership talk', Human Relations, 65(8): 979-999.

Kirton, G. and Healy, G. (2004). Shaping union and gender identities: a case study of women-only trade union courses. British Journal of Industrial Relations, 42(2) : 30324.

Le Brouster, P. (2009). 'Le débat sur la mixité des structures au sein de la CFDT (19761982)', Sens Public 5: 3-12.

Ledwith, S., Colgan, F., Joyce, P. and Hayes, P. (1990). 'The making of women trade union leaders', Industrial Relations Journal, 21(2): 112-125.

Lenzi, C. (2009). 'L'injonction à l'autonomie comme mode de sélection sociale des militants des SEL'. In: Nicourd S. (ed.), Le travail militant. Rennes: Presses universitaires de Rennes, pp. 95-106.

Le Quentrec, Y. and Rieu, A. (2003) Femmes : engagements publics et vie privée, Paris: Editions Syllepse.

McAdam D. (1986). 'Recruitment to High-Risk Activism: The Case of Freedom Summer'. American Journal of Sociology, 92(1): 64-90. 
McBride, A. (2001). Gender, Democracy in Trade Unions. Aldershot: Ashgate.

Mcllroy, J. (2012). 'Radical political unionism reassessed'. European Journal of Industrial Relations, 18(3): 251-258.

Mélis, C. (2010) “"Des syndicalistes comme les autres ?”. L'expérience syndicale de migrantes et de filles d'immigrés d'Afrique du Nord et Sub-saharienne', L'Homme et la Société, 2:176-77.

Milkman, R. (2016). On Gender, Labor, and Inequality. Chicago: University of Illinois Press.

Milkman, R. (1990). 'Gender and Trade Unionism in Historical Perspectives'. In: Tilly L.A. and Gurin, P. (eds.) Women, Politics, and change. New York: The Russel Sage Foundation, p.87-107.

Moore, S. (2011). New trade union activists - class consciousness or social identity?. Basingstoke: Palgrave Macmillan.

Parker, J. (2006). 'Towards equality and renewal: Women's groups, diversity and democracy in British unions'. Economic and Industrial Democracy, 27(3): 425-462.

Pochic, S. (2014). 'Femmes responsables syndicales en Angleterre et identification féministe : neutraliser leur genre pour mieux représenter leur classe ?’. Sociologie, 5(4): 369-386.

Saundry, R. and McKeown, M. (2013). 'Relational union organizing in a healthcare setting: a qualitative study'. Industrial Relations Journal, 44(5): 533-547.

Sayce, S., Greene, A.M. and Ackers, P. (2006). 'Small is beautiful ? The development of women's activism in a small union'. Industrial Relations Journal, 37(4): 400-414.

Shaw, M. and Mundy, M. (2005). 'Complexities of class and gender relations: Recollections of women active in the 1984-5 miner's strike'. Capital and Class, 29: 151-174.

Skeggs, B. (1997). Formation of Class and Gender. Becoming Respectable. London: Sage. 
Taylor, P. and Moore, S. (2014). 'Cabin crew collectivism: labour process and the roots of mobilization'. Work, employment and society, 29(1): 79-98.

Trat, J. (2006). 'La responsable féministe, la « mauvaise tête » dans les organisations mixtes'. Cahiers du Genre, 3(1): 143-158.

Yates, C. (2010). ‘Understanding caring, organizing women: how framing a problem shapes union strategy'. Transfer: European Review of Labour and Research, 16(3): 399-410.

Yates, C. (2006). 'Challenging Misconceptions about Organizing Women into Unions'. Gender, Work and Organization, 13(6): 565-584.

Wilkes, R. (2004). 'First Nation politics: Deprivation, resources, and participation in collective action'. Sociological Inquiry, 74(4): 570-589.

Wolf, G. (2011). L'espace de la cause des femmes à la création des syndicats SUD (19881998). Mémoire de Master-2 Histoire, Université d'Angers. 
Table 1: Interviewees' profiles

\begin{tabular}{|c|c|c|c|c|c|c|}
\hline Union & Union role & Occupation & $\begin{array}{l}\text { Employment } \\
\text { Status }\end{array}$ & Education & Age & Children \\
\hline SNUI & Member & $\begin{array}{l}\text { Employee } \\
\text { (tax officer) }\end{array}$ & Public sector & $\begin{array}{l}\text { Master in } \\
\text { History }\end{array}$ & $40-45$ & 1 \\
\hline SNUI & $\begin{array}{l}\text { Branch } \\
\text { officer }\end{array}$ & Manager & Public sector & Master in Law & $40-45$ & 2 \\
\hline Sud Opéra & Member & Technician & Public sector & $\begin{array}{l}\text { Professional } \\
\text { diploma in } \\
\text { make-up }\end{array}$ & $35-40$ & 0 \\
\hline SUD Opéra & $\begin{array}{l}\text { Shop } \\
\text { Steward }\end{array}$ & Technician & Public sector & A levels & $45-50$ & 0 \\
\hline Sud Chimie & Union rep & Technician & $\begin{array}{l}\text { Private } \\
\text { sector }\end{array}$ & $\begin{array}{l}\text { Chemistry } \\
\text { HNC }\end{array}$ & 40 & 2 \\
\hline Solidaires & $\begin{array}{l}\text { (ex) } \\
\text { General } \\
\text { Secretary }\end{array}$ & $\begin{array}{l}\text { Employee } \\
\text { (postal } \\
\text { worker) }\end{array}$ & Public sector & Master & $60-65$ & 1 \\
\hline Solidaires & $\begin{array}{l}\text { General } \\
\text { Secretary }\end{array}$ & $\begin{array}{l}\text { Employee } \\
\text { (postal } \\
\text { worker) }\end{array}$ & Public sector & $\begin{array}{l}\text { Master in } \\
\text { Psychology }\end{array}$ & $45-50$ & 0 \\
\hline Solidaires & $\begin{array}{l}\text { Education } \\
\text { officer }\end{array}$ & $\begin{array}{l}\text { Social } \\
\text { Worker }\end{array}$ & Public sector & $\begin{array}{l}\text { Master in } \\
\text { Psychology }\end{array}$ & $45-50$ & 0 \\
\hline Solidaires & $\begin{array}{l}\text { National } \\
\text { official }\end{array}$ & $\begin{array}{l}\text { Employee } \\
\text { (employment } \\
\text { counselor) }\end{array}$ & Public sector & $\begin{array}{l}\text { Diploma in } \\
\text { Social Work }\end{array}$ & $60-65$ & 0 \\
\hline SUD-Rail & $\begin{array}{l}\text { Branch } \\
\text { officer }\end{array}$ & $\begin{array}{l}\text { Employee } \\
\text { (sales } \\
\text { assistant) }\end{array}$ & Public sector & A levels & $30-35$ & 0 \\
\hline SUD-Rail & $\begin{array}{l}\text { National } \\
\text { official }\end{array}$ & Manager & Public sector & A levels & $50-55$ & 1 \\
\hline SUD-Rail & $\begin{array}{l}\text { Shop } \\
\text { Steward }\end{array}$ & Train driver & Public sector & A levels & $40-45$ & 3 \\
\hline SUD Emploi & $\begin{array}{l}\text { Branch } \\
\text { officer }\end{array}$ & $\begin{array}{l}\text { Employee } \\
\text { (employment } \\
\text { counselor) }\end{array}$ & Public sector & $\begin{array}{l}\text { Master in } \\
\text { Sociology }\end{array}$ & $60-65$ & 1 \\
\hline SUD Santé & $\begin{array}{l}\text { National } \\
\text { Official }\end{array}$ & Nurse & Public sector & $\begin{array}{l}\text { Diploma in } \\
\text { Nursing }\end{array}$ & $40-45$ & 1 \\
\hline SUD Santé & $\begin{array}{l}\text { National } \\
\text { official }\end{array}$ & Nurse & Public sector & $\begin{array}{l}\text { Diploma in } \\
\text { Nursing }\end{array}$ & $60-65$ & 2 \\
\hline SUD Santé & $\begin{array}{l}\text { Shop } \\
\text { Steward }\end{array}$ & $\begin{array}{l}\text { Social } \\
\text { Worker }\end{array}$ & Public sector & $\begin{array}{l}\text { Diploma in } \\
\text { Social Work }\end{array}$ & $55-60$ & 1 \\
\hline SUD-PTT & $\begin{array}{l}\text { National } \\
\text { official }\end{array}$ & $\begin{array}{l}\text { Employee } \\
\text { (postal } \\
\text { worker) }\end{array}$ & $\begin{array}{l}\text { Private } \\
\text { sector }\end{array}$ & A levels & $40-45$ & 3 \\
\hline SUD-PTT & $\begin{array}{l}\text { Shop } \\
\text { steward }\end{array}$ & $\begin{array}{l}\text { Employee } \\
\text { (postal } \\
\text { worker) }\end{array}$ & Public sector & A levels & $30-35$ & 0 \\
\hline
\end{tabular}




\begin{tabular}{|c|c|c|c|c|c|c|}
\hline $\begin{array}{l}\text { SUD } \\
\text { Douanes }\end{array}$ & $\begin{array}{l}\text { Branch } \\
\text { officer }\end{array}$ & $\begin{array}{l}\text { Employee } \\
\text { (custom } \\
\text { officer) }\end{array}$ & Public sector & $\begin{array}{l}\text { Master in } \\
\text { Business }\end{array}$ & $40-45$ & 4 \\
\hline SUD Travail & $\begin{array}{l}\text { Branch } \\
\text { officer }\end{array}$ & $\begin{array}{l}\text { Labor } \\
\text { inspector }\end{array}$ & Public sector & Master in Law & $30-35$ & 0 \\
\hline $\begin{array}{l}\text { SUD } \\
\text { Collectivités } \\
\text { Locales }\end{array}$ & $\begin{array}{l}\text { National } \\
\text { Official }\end{array}$ & $\begin{array}{l}\text { Social } \\
\text { Worker }\end{array}$ & Public sector & $\begin{array}{l}\text { Diploma in } \\
\text { Social Work }\end{array}$ & $40-45$ & 2 \\
\hline SNUPFEN & $\begin{array}{l}\text { Branch } \\
\text { officer }\end{array}$ & $\begin{array}{l}\text { Forest } \\
\text { engineer }\end{array}$ & Public sector & $\begin{array}{l}\text { Master in } \\
\text { Oceanography }\end{array}$ & $55-60$ & 1 \\
\hline $\begin{array}{l}\text { SUD } \\
\text { Industrie }\end{array}$ & Member & Technician & $\begin{array}{l}\text { Private } \\
\text { sector }\end{array}$ & $\begin{array}{l}\text { Diploma in } \\
\text { Plumbing } \\
\text { Services }\end{array}$ & $40-45$ & 1 \\
\hline $\begin{array}{l}\text { Sud } \\
\text { Education }\end{array}$ & Member & Teacher & Public sector & $\begin{array}{l}\text { Master in } \\
\text { Literature }\end{array}$ & $40-45$ & 0 \\
\hline $\begin{array}{l}\text { Sud } \\
\text { Education }\end{array}$ & $\begin{array}{l}\text { Branch } \\
\text { Officer }\end{array}$ & Teacher & Public sector & $\begin{array}{l}\text { Master in } \\
\text { Archeology }\end{array}$ & $30-35$ & 1 \\
\hline SNJ & $\begin{array}{l}\text { Shop } \\
\text { Steward }\end{array}$ & Journalist & $\begin{array}{l}\text { Private } \\
\text { sector }\end{array}$ & A Levels & $60-65$ & 1 \\
\hline SNJ & $\begin{array}{l}\text { National } \\
\text { official }\end{array}$ & Journalist & $\begin{array}{l}\text { Private } \\
\text { sector }\end{array}$ & $\begin{array}{l}\text { Master in } \\
\text { Political } \\
\text { Science }\end{array}$ & $40-45$ & 1 \\
\hline SNJ & $\begin{array}{l}\text { Shop } \\
\text { Steward }\end{array}$ & Journalist & $\begin{array}{l}\text { Private } \\
\text { sector }\end{array}$ & A Levels & $60-65$ & 2 \\
\hline $\begin{array}{l}\text { SUD } \\
\text { Culture }\end{array}$ & $\begin{array}{l}\text { Branch } \\
\text { officer }\end{array}$ & $\begin{array}{l}\text { Employee } \\
\text { (museum } \\
\text { guard) }\end{array}$ & Public sector & $\begin{array}{l}\text { Master in Art } \\
\text { History }\end{array}$ & $40-45$ & 2 \\
\hline $\begin{array}{l}\text { SUD } \\
\text { Culture }\end{array}$ & $\begin{array}{l}\text { National } \\
\text { Official }\end{array}$ & $\begin{array}{l}\text { Employee } \\
\text { (museum } \\
\text { guard) }\end{array}$ & Public sector & $\begin{array}{l}\text { Master in } \\
\text { Political } \\
\text { Science }\end{array}$ & $35-40$ & 1 \\
\hline
\end{tabular}


Table 1: Selected respondent characteristics (145 respondents)

\begin{tabular}{|c|c|c|c|}
\hline & $\begin{array}{c}\text { Proportion of } \\
\text { respondents (\%) }\end{array}$ & & $\begin{array}{c}\text { Proportion of } \\
\text { respondents (\%) }\end{array}$ \\
\hline Gender & & Employer & \\
\hline Male & 5 & $\begin{array}{r}\text { Public administrations (local and } \\
\text { central government, hospitals, } \\
\text { schools) }\end{array}$ & 40 \\
\hline Female & 95 & Public companies & 31 \\
\hline Age & & Private companies > 500 employees & 14 \\
\hline$<30$ & 0 & Other & 5 \\
\hline $30-39$ & 15 & Children age & \\
\hline $40-49$ & 25 & $0-10$ & 17 \\
\hline $50-59$ & 47 & $11-15$ & 14 \\
\hline $60+$ & 13 & $16-20$ & 28 \\
\hline $\begin{array}{r}\text { Level of } \\
\text { education }\end{array}$ & & $>20$ & 64 \\
\hline$<$ A Levels & 25 & Occupation & \\
\hline A Levels & 19 & $\begin{array}{r}\text { Managers, directors and senior } \\
\text { officials }\end{array}$ & 12 \\
\hline $\begin{array}{r}\text { Bachelor } \\
\text { degree }\end{array}$ & 32 & Professional occupations & 26 \\
\hline $\begin{array}{l}\text { Master } \\
\text { degree }\end{array}$ & 24 & $\begin{array}{r}\text { Associate professional and technical } \\
\text { occupations }\end{array}$ & 24 \\
\hline $\begin{array}{r}\text { Employment } \\
\text { status }\end{array}$ & & $\begin{array}{r}\text { Administrative and secretarial } \\
\text { occupations }\end{array}$ & 29 \\
\hline Public sector & 75 & $\begin{array}{r}\text { Skilled trades occupations; service } \\
\text { occupations; process, plant and } \\
\text { machine operatives }\end{array}$ & 9 \\
\hline Private sector & 15 & Work hours & \\
\hline Retired & 10 & Full-time & 75 \\
\hline & & Part-time & 25 \\
\hline
\end{tabular}

